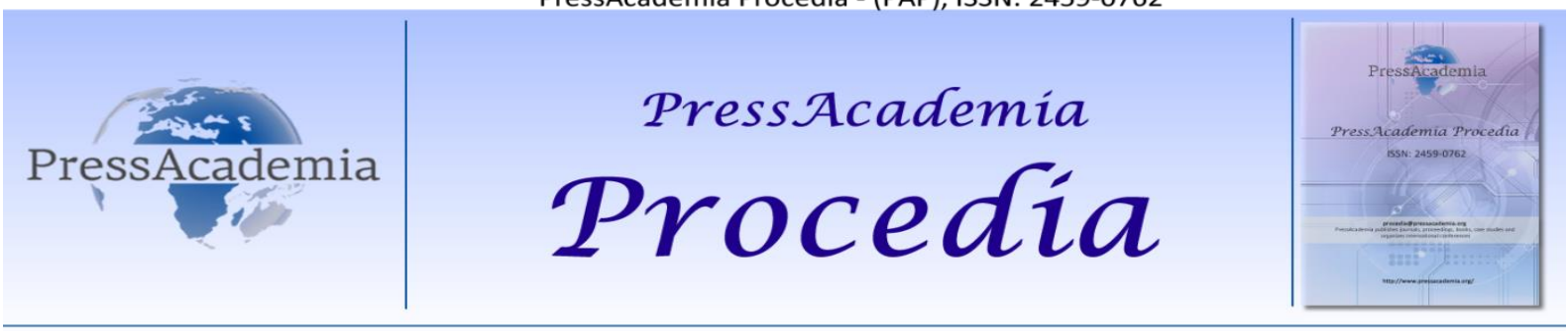

Global Business Research Congress (GBRC), May 24-25, 2017, Istanbul, Turkey.

\title{
THE COMPARISON OF CONSUMERS' VALUES AND LIFESTYLES ACCORDING TO FREQUENCY OF VISITING SHOPPING CENTERS: MALATYA PROVINCE EXAMPLE
}

\section{DOI: 10.17261/Pressacademia.2017.647}

PAP- GBRC-V.3-2017(73)-p.707-715

\author{
Yildirim Yiidirim ${ }^{1}$, Onder Kethuda ${ }^{2}$ \\ ${ }^{1}$ Duzce University, Akcakoca School of Tourism and Management, Duzce, Turkey. yildirimyildirim@duzce.edu.tr \\ ${ }^{2}$ Duzce University, Akcakoca School of Tourism and Management, Duzce, Turkey. onderkethuda@duzce.edu.tr
}

\section{To cite this document}

YIIdırım, Y. and O. Kethuda (2017). The comparison of consumers' values and lifestyles according to frequency of visiting shopping centers: Malatya province example. PressAcademia Procedia (PAP), V.3, p.707-715.

Permemant link to this document: http://doi.org/10.17261/Pressacademia.2017.647

Copyright: Published by PressAcademia and limited licenced re-use rights only.

\begin{abstract}
The purpose of this study is to compare values and lifestyles the consumers according to the frequency of visits to shopping centers. Furthermore, determining the lifestyles of the people who visit shopping centers is another object of the research. The questionnaire was used as data collection tool. The questionnaire contains questions to learn about participants' values, lifestyles and demographics. The population of the study consists of people over 17 years old and living in the Battalgazi and Yeşilyurt districts of Malatya. Kota sampling method, one of the non-random sampling methods, has been used as sampling method in the research. Data were collected from 450 individuals in the population and the data were analyzed by SPSS. The findings indicate that values and lifestyles of consumers differ according to their visiting frequency of shopping centers. From the value perspective, it has been seen that those who visit the shopping center "every day" predominate the values of happiness, pleasure, excitement and self-esteem in life. When it is evaluated in terms of lifestyle, it is seen that discount followers do not go to the shopping centers much, but consumers who follow brand and fashion trends, the innovations and technology and identified as a leader, visit the shopping center every day. The results of this research might bring a new perspective to administrations of shopping centers by showing what values and lifestyles motivate people to visit shopping centers. Results might play an important role in attracting more consumers to shopping centers.
\end{abstract}

Keywords: Consumer behaviours, values, lifestyles, shopping centers, frequency of shopping centers.

JEL Codes: M3, M30, M31

\section{TÜKETICILERIN DEĞERLERININ VE YAŞAM TARZLARININ ALIŞVERIŞ MERKEZLERINI ZiYARET ETME SIKLIĞINA GÖRE KARŞILAŞTIRILMASI: MALATYA İİ ÖRNEĞi}

\section{ÖZET}

Bu çalışmanın amacı, tüketicileri alışveriş merkezlerini ziyaret etme sıklıklarına göre tüketim değerlerini ve yaşam tarzlarını karşılaştırmaktır. Ayrıca, alışveriş merkezlerini ziyaret edenlerin yaşam tarzlarını belirlemek araştırmanın bir diğer amacıdır. Veri toplama aracı olarak anket yöntemi kullanılmıştır. Anket formu, katılımcıların değerlerini, yaşam tarzlarını ve demografik özelliklerini öğrenmeye yönelik soruları içermektedir. Araştırma evreni Malatya'nın Battalgazi ve Yeşilyurt ilçelerinde yaşayan 18 yaş ve üzeri nüfus oluşturmaktadır. Araştırmada örnekleme yöntemi olarak tesadüfi olmayan örnekleme yöntemlerinden kota örneklem yöntemi kullanılmıştır. Araştırma kapsamında 450 kişiden veri toplanmıştır ve toplanan veriler SPSS ile analiz edilmiştir. Analiz sonuçlarına göre, farklı değerlere ve yaşam tarzlarına sahip olan tüketicilerin alışveriş merkezlerini ziyaret sıklıkları farklılık göstermektedir. Değerler yönünden bakıldığında alışveriş merkezini "her gün" ziyaret edenlerin daha çok yaşamda mutluluk ve haz, heyecan arama ve öz saygı değerlerini öncelediği görülmüştür. Yaşam tarzı açısından değerlendirildiğinde ise indirim takipçilerinin alısveriş merkezlerine pek gitmediği, marka ve modaya düşkün, yenilikleri ve teknolojiyi takip eden, lider ruhlu tüketicilerin alışveriş merkezini her gün ziyaret ettikleri ve sağlıklarına dikkat edenlerin ise alışveriş merkezine daha çok fırsat bulduklarında gittikleri görülmüştür. Bu araştırmanın sonuçları, hangi değerlere ve yaşam tarzlarına sahip insanları alışveris merkezlerini daha fazla ziyaret etmeye motive ettiğini göstermesi nedeniyle, alışveriş merkezlerinin yönetimlerine yeni bir bakış açısı kazandırabilir. Bu sonuçlar, alışveriş merkezlerine daha fazla tüketicinin ilgisini çekmede önemli bir rol oynayabilir.

Anahtar Kelimeler: Tüketici davranışları, değerler, yaşam tarzı, alışveriş merkezleri, AVM ziyaret sıklığı,

JEL Kodları: M3, M30, M31 


\section{GiRiş}

Geçmişten günümüze alışveriş mekânlarının toplayıcı, sosyal etkileşimi arttırıcı ve temel alışveriş eyleminin gerçekleştiği mekânlar olma niteliği değişmemiştir (Verdil, 2007: 1). Alışveriş merkezleri, son yirmi yılda gündelik hayatın önemli bir parçası haline gelmiştir. Alışveriş merkezleri (AVM) ürün çeşitliliği, hizmet kalitesi ve tüketicilerin tüm ihtiyaçlarına tek bir çatı altında cevap verebilme imkânının yanı sıra, kişilerin ve aile bireylerinin birlikte, hoşça vakit geçirmeleri için etkinlikler hazırlayarak, sosyal intiyaçlara da hitap edebilen özellikleriyle, bulundukları şehirlere renk ve canlılık katmaktadır. Bu anlamda alışveriş merkezleri, sosyo-kültürel etkinlikleri ve algılanan yapısıyla insanların sadece alışveriş yapmak için geldikleri yer olmanın ötesine geçerek hem tüketim mekânları hem de sosyal ve kültürel mekânlara dönüşmüşlerdir (Köksal ve Aydın, 2015: 232-234). Alışveriş merkezinin sosyal atmosferi, onun popülerliğine ve kârılığına katkıda bulunmaktadır (Çakmak, 2012: 198). Modernleşme, sanayileşme ve kentleşme süreçlerinin bir ürünü olan bu mekânlar, insanların boş zamanlarını burada gezerek, eğlenerek, alışveriş yaparak ve dinlenerek değerlendirmesine olanak sunmakta ve bir yandan tüketimi hızlandırmaktadır. Zira alışveriş merkezi tüketicilerinin satın alma davranışı üzerine Bursa ilinde yapılan bir araştırmaya göre AVM'ye gitme nedenleri arasında alışveriş, gezinti, arkadaşlarla buluşma ve misafirleri gezdirme gibi nedenler gösterilmiştir (Akat, Taşkın ve Özdemir, 2012: 21). Yapılan bir başka araştırmada ise alışveriş merkezine gitme nedenleri arasında eğlenmek ve boş zamanları geçirme imkânının bulunması, sosyalleşme imkânını tanıması ve alışveriş merkezinde alışveriş yapmanın haz ve tatmin sağlaması gibi nedenler yüksek oranda etkili olarak bulunmuştur (Yılmaz ve Karaman, 2012: 407).

Tüketim toplumunda AVM'lerde farklı amaçlarla vakit geçirmek gündelik bir faaliyet gibi görülmesinin yanında, AVM yöneticileri de buraların insanların uğrak yeri olması için ciddi çaba sarf etmektedir. Çünkü yönetim AVM'yi cazibe merkezi haline getirdikçe daha iyi markalarla daha iyi anlaşmalar yapabilmekte ve AVM'nin kazancını artırabilmektedir. Bu nedenle, AVM'ler üzerinde yapılan araştırmalar pazarlama literatürü için önem arz etmektedir. AVM'ler ile ilgili pazarlama alanında yapılan araştırmaları ikiye ayırmak mümkündür. Birinci grup çalışmalar, tüketicilerin AVM'lere gitme motivasyonlarını incelerken ikinci grup çalışmalar AVM'lerin hangi özelliklerinin tüketicileri çektiğini ve cezbettiğini incelemektedir (Yaraş, Özbük ve Göncü, 2016: 276). Bu çalışmanın odağında tüketicilerin AVM'ye gitme sıklığı bulunmaktadır. AVM'ye gitme nedenleri, tüketicilere göre çok farklılıklar gösterebilmektedir. Bunun yanında, AVM'ye gitmede en önemli faktörlerin değerler ve yaşam tarzı olduğu düşünülmektedir. Yaşam tarzı kavramı, kişilerin paralarını ve zamanlarını nasıl harcadıkları ile ilgilenirken; değerler, neyin doğru neyin yanlış olduğu konusunda kişilere fikir veren ve bir ölçüt sunan standartlar olarak tanımlanmaktadır. Farklı değerlere ve yaşam tarzına sahip olan tüketiciler alışveriş merkezinde kendilerine göre birer aktivite bulabilmektedir (Vural ve Yücel, 2006: 104). Bu çalışmanın amacı, tüketicileri alışveriş merkezlerini ziyaret etme sıklıklarına göre tüketicilerin değerlerini ve yaşam tarzlarını karşılaştırmak ve dolayısıyla hangi değerlerin ve yaşam tarzlarının alışveril merkezini ziyaret etmeye motive ettiğini ortaya koymaktır.

\section{LITERATÜR INCELEMESi}

Yirminci yüzyıldan sonra tüketim olgusu sadece ekonomik açıdan kişiye yarar sağlayan bir olgu olmaktan çıkmış; onun yerine gösterge ve sembollerin de içinde olduğu bir sosyal ve kültürel süreç olmaya doğru yol almıştır. Böylece üretilen malların gösterge ve semboller kullanılarak tüketicilerin çoğuna satılmasıyla, tüketim ile arzular arasında bir ilişki kurulmuştur. Günümüzdeki insana "sizi mutlu eden şey nedir?" diye bir soru sorulduğunda "arzu ettiğimiz her şeyi alabilmek" cevabı verilebilmektedir (Şentürk, 2012: 67-68). Hazcı tüketimin gerçekleştiği ve ürünlerin rasyonel faydalarından uzaklaşıp birer gösterge ve sembole dönüştüğü yerlerin başında gelen alışveriş merkezleri, yaşam tarzının en bariz olarak uygulandığı yerler olarak karşımıza çıkmaktadır. Yaşam tarzı çok boyutlu bir kavram olup ona dışarıdan nasıl baktığımızla ilgilidir. Bu kavramın psikoloji, sosyoloji, siyaset, eğitim ve iktisatla yakın ilişkili olduğu söylenebilir (Soininen ve Storm, 2010). Yaşam tarzı, insanların modern dünyadaki günlük yaşamlarında neyi, niçin yaptıklarını ve yaptıkları şeylerin ne anlama geldiğini anlamada yardımcı olan bir kavramdır (Kahraman, 2011: 2). Her bireyin yaşam tarzı onun kişiliğini, kişisel değerlerini, yaşama ait görüşünü, estetik anlayışını ve amaçlarını yansıtır. Bu da kişinin ürün ve marka tercihlerini, gittiği yerleri ve ne sıklıkta gittiğini etkiler. Hatta cep telefonunda kullandığı arama müziği bile onun kim olduğu hakkında karşı tarafa bir fikir verir (Catalin ve Andreea, 2014: 104). Değerler, yaşam tarzının en önemli belirleyicisidir. Bireyin tüketim kalıpları üzerinde yaşam tarzı ve kişisel değerlerinde önemli etkisi olduğu bilinmektedir. Bireyin tutum, görüş ve davranışlarında bir kriter olarak görülen değerler, kişinin önem verdiği şeyleri tanımlar, böylece onun tercihlerini, istediklerini ve istemediklerini gösterir (Bozgeyikli, 2010: 1798). Tüketiciler, yukarıda ifade edildiği gibi, çok farklı nedenlerle alışveriş merkezlerine gidebilmektedirler (Kim, 2002: 601). Bu durum, tüketicilerin farklı amaçlarla alışveriş merkezlerine gidebileceklerini göstermektedir. Bir ürünün ifade ettiği fonksiyonlar kişinin değerlerine göre farklılık gösterebilmesi ve kişinin değerlerine göre ürün birçok farklı anlama gelebilmesi gibi alışveriş merkezine gitme veya gitmeme amaçları da tüketicilerin değerlerine göre farklılık gösterebilmektedir (Kahle, 1986: 44). Tüketicilerin alışveriş merkezlerinmi ziyaret etme amaçlarının değerlere göre farklılık göstermesi gibi, bu tüketicilerin değerlerine göre alışveriş merkezlerini ziyaret etme sıklıkları da farklılık gösterebilir. Bu doğrultuda geliştirilen hipotez şu şekildedir: 
$\mathrm{H}_{1}$ : Tüketicilerin sahip oldukları değerler, alışveriş merkezine gitme sıklığına göre farklılık göstermektedir.

Perakendeciliğin eğlence yönü önemli bir rekabet aracı olarak giderek önemini arttırmaktadır. Bu anlamda bir perakendecinin geleneksel anlayışla müşteriyi yalnızca bol çeşit, düşük fiyat ve geçirilen uzun mağaza saatleri ile cezbetmesi mümkün olmamaktadır (Arnold ve Reynolds, 2003: 77). Alışveriş üzerine yapılan araştırmalar uzunca bir süre alışverişin faydacı yönlerine odaklanmış ve alışveriş eylemini yerine getirilmesi gereken bir görev olarak tanımlamıştı. Bu anlamda ürün/hizmetin satın alınması görevin başarıyla yerine getirildiği anlamına geliyordu. Ancak bu anlayış alışveriş deneyiminin bütününü açıklamada yetersiz kalmaktaydı. Bu yüzden de son birkaç yıldır yapılan araştırmalar (Babin vd., 1994; Langrehr, 1991; Roy, 1994; Wakefield ve Baker, 1998) alışverişin duygusal ve hazcı yönüne odaklandı ve eğlence, rahatlama ve keyif faktörlerinin alışveriş davranışı üzerindeki etkilerinin önemini anlamaya başladı. Bazı müşteriler gerçekten ürün satın almaktan, mağaza dolaşmaktan ve hazcı alışveriş deneyimi yaşamaktan büyük keyif almaktadırlar. Bu tip tüketiciler için alışveriş vazgeçilmez bir boş zaman faaliyeti ve dinlenme-rahatlama aracıdır. Bu tüketiciler alışverişin rasyonel ve faydacı yanlarından ziyade kendilerine sağladığı psikolojik ve ruhsal kazanımlarla ilgilenirler (Kim ve Kim, 2008: 411). Keyif için alışveriş yapan ve hazcı duygularıyla hareket eden bir tüketici, aradığını bulamasa bile alışverişi bir macera ve heyecan olarak görmeye devam etmekte, bakılacak daha çok mağazanın olduğunu söylemektedir (Babin vd., 1994: 646). Örneğin, Noel alışverişçileri tatil alışverişinde bulunduklarında kendilerini "şeker dükkânındaki çocuk" olarak tanımlamışlardır. Bu durum artan heyecanı, başkaları için hediye almanın zevkini ve alışveriş keyfi için bir uyarılma durumunu ifade etmektedir (Arnold ve Reynolds, 2003: 78). Taylor ve Cosenza (2002: 403) tarafından yapılan araştırmada, alışveriş merkezi tarafından oluşturulan heyecan düzeyinin 16-20 yaş arası genç kızlarda önemli bir etki oluşturduğuna işaret edilmekte ve genç kızları "mağazada doğmuş tüketiciler" olarak adlandırılmaktadır. Buradan hareketle birinci hipoteze ilişkin alt hipotezler şu şekildedir:

$\mathrm{H}_{1.1}$ : Heyecan arama değeri ile yaşamda mutluluk ve haz değerlerine sahip tüketicilerin alışveriş merkezine gitme sıklığı diğerlerine göre daha yüksektir.

$\mathrm{H}_{1.2}$ : Sınıflandırılmış kişisel değerler itibariyle hazcı değere sahip tüketiciler alışveriş merkezlerine daha sık oranda gitmektedirler.

Alışveriş merkezleri tüketicilerin yaşam tarzlarında önemli bir rol oynamaktadır (Terblanche, 1999). Alışveriş merkezleri, sadece alışveriş yapılan yerler değil, aynı zamanda toplumsal ve eğlence amaçlı faaliyetlerin yerine getirildiği bir kültür merkezi konumundadır (Ng, 2003). Mağazalar, yemek alanları, sinemalar, restoranlar, çocuk oyun alanları interaktif eğlenceler, sosyal kullanım alanları ve dinlenme alanları herhangi bir alışverişin artık ana bileşenleri arasında sayılmaktadır. Bloch ve arkadaşları (1989) tüketicilerin rekreasyonel (eğlence ve dinleme) faydalar elde etmek için alışveriş merkezlerinde vitrinlere göz attıklarını, dolaştıklarını belirtmektedir. AVM'lerin sayısındaki artış tüketicileri seçici olmaya zorlamaktadır. Bir tüketici AVM tercihi yaparken içinde çok sayıda farklı mağaza olmasını, atmosfer ve diğer özellikler bakımından rahat ve çekici olmasını ve içeride sunulan imkanların kendi yaşam tarzıyla örtüşmesini beklemektedir (Wong vd., 2001). Erkip'te (2005) alışveriş merkezleri ile ilgili yaptığı çalışmasında AVM’leri Türk kentsel yaşam tarzının bir parçası olarak görmekte ve bu mekânların kişilerin yaşam tarzlarına ilişkin ipuçları verdiğini söylemektedir. Bu durum, bazı yaşam tarzlarının tüketicileri alışveriş merkezlerine gitmeye motive ettiği anlamına gelmektedir. Alışveriş merkezine gitmeye motive eden yaşam tarzına sahip olan tüketicilerin alışveriş merkezlerini daha fazla ziyaret etmeleri beklenmektedir. Buradan hareketle geliştirilen ikinci hipotez şu şekildedir:

$\mathrm{H}_{2}$ : Tüketicilerin yaşam tarzları, alışveriş merkezine gitme sıklıklığına göre farklılık göstermektedir.

\section{VERI VE YÖNTEM}

Veri toplama aracı olarak anket yöntemi kullanılmıştır. Anket, demokrafik özellikler, değerler ve yaşam tarzı ile ilgili soruları içeren üç farklı bölümden oluşmaktadır. Tüketicilerin yaşam tarzını ölmeye yönelik sorular VALS ölçeğinden yararlanılarak oluşturulmuştur. Anketin bu bölümünde, tüketicilerin yaşam tarzlarına yönelik olarak onların faaliyetlerini, ilgilerini, kendileri ve çevreleri hakkındaki düşündüklerini, neye önem verdiklerini, neye önem vermediklerini ve sevdikleri ile sevmedikleri şeyleri öğrenmeye ilişkin 43 soru yer almaktadır. Bu ifadeler tüketicilerin "Marka ve moda delileri", "Lider ruhlular", "Yenilik ve teknoloji ustaları", "Evcimenler”, "Sağlıkçılar”, "Indirim takipçileri” şeklinde yaşam tarzı alt gruplarına ayrılacak şekilde sorulmuştur. Anketin ikinci bölümünde ise; Kahle'nin değerler listesi verilmiş ve tüketicilerden bu değerleri kendi önem sıralarına göre 1= kesinlikle önemsiz, 5= kesinlikle önemli olacak şekilde 1'den 5'e kadar sıralamaları istenmiştir. Kahle'nin (1986) değerler ölçeği; yaşamda mutluluk ve haz, heyecan arama, diğer insanlarla iyi ilişkiler kurma, öz saygı, diğer bireylerden saygı görme, güvende olma, aidiyet değeri, kişisel gelişim ve başarma duygusu değerlerinden oluşmaktadır. Kahle'nin (1986) ölçeğindeki boyutlar ayrıca, hazcı değerler(yaşamda mutluluk ve haz, heyecan arama, diğer insanlarla iyi ilişkiler kurma), empatik değerler (öz saygı, diğer bireylerden saygı görme, güvende olma, aidiyet değeri) ve kendini gerçekleştirme değerler (kişisel gelişim ve başarma duygusu) olarak sınıflandırılabilmektedir. Anketin son bölümünde ise cevaplayıcıların demografik özelliklerine yönelik sorular yer almaktadır. 
Araştırma evreni olarak Malatya il merkezini kapsayan Battalgazi ve Yeşilyurt ilçelerinde yaşayan 18 yaş ve üzeri nüfus belirlenmiş ve çevre ilçeler araştırmaya dâhil edilmemiştir. Bu iki ilçenin 18 yaş ve üzeri toplam nüfusu 401.060 kişidir. Örnekleme kitaplarında yer alan ve makalelerde, yabancı literatürde örnek hacminin belirlenmesine yönelik olarak oluşturulan tablo referans alınmış ve bu kapsamda 384 anketin örnek hacmi için yeterli olabileceği görülmüştür (Krejcie ve Morgan, 1970: 608; Yazıcıoğlu ve Erdoğan, 2014: 50). Ancak, cevaplanmama veya yanlış/eksik cevaplanma ihtimalinin \%10 olduğu varsayılarak ve örnek hacmi büyüklüğü ne kadar fazla olursa ana kütleyi temsil etme kabiliyetinin o kadar artacağı düşüncesinden hareketle anket sayısı 450'ye çıkarılmıştır. Araştırmada örnekleme yöntemi olarak tesadüfi olmayan örnekleme yöntemlerinden biri olan kota örneklem yöntemi kullanılmıştır. Buna göre Malatya'nın iki merkez ilçesi olan Battalgazi ve Yeşilyurt ilçeleri önce mahallelere daha sonra cadde ve sokaklara ayrılmıştır. Daha sonra seçilen sokaklarda anketi cevaplamaya gönüllü kişilerle araştırma gerçekleştirilmiştir.

\section{BULGULAR VE TARTIŞMA}

Katılımcıların \%50,2'si ( $n=226)$ erkeklerden ve \%49,8'i $(n=224)$ is kadınlardan oluşmaktadır. Katılımcıların \%61,1'i $(n=275)$ evli, \%37,3'ü ( $n=168$ ) bekâr olarak dağııırken; \%2'si ( $n=9)$ okuma yazması yok, \%8,2'si ( $n=37)$ ilköğretim, \%17,8'i $(n=80)$ lise, $\% 52,4$ 'ü ( $n=236)$ ön lisans/lisans, \%19,6'sı $(n=88)$ lisansüstü olarak dağılmaktadır. Katılımcıların \%12,2'si $(n=55)$ 18-25, $\% 46,4$ 'ü $(n=209)$ 26-35, \%28,9'u $(n=130)$ 36-45, \%9,8'i $(n=44) 46-55, \% 2,7$ 'si $(n=12) 55$ yaş aralığındadır. Katılımcıların hane halkı geliri; \%20,2'si ( $n=91)$ 1000-2000 TL, \%24,4'ü ( $n=110)$ 2001-4000 TL, \%35,3'ü ( $n=159)$ 4001-6000 TL, \%12,0'ı ( $n=54)$ 6001-8000 TL, \%8,0'ı (n=36) 8000 TL üstü olarak dağılmaktadır.

Yaşam tarzı ölçeğinin yapı geçerliliğini ortaya koymak için keşfedici faktör analizi yöntemi uygulanmıştır. Faktör analizi uygulamasında Varimax dik döndürme yöntemi seçilerek faktörler arasındaki ilişkinin yapısının aynı kalması sağlanmıştır. Faktör analizi sonucunda değişkenler toplam açıklanan varyansı \%62.442 olan 6 faktör altında toplanmıştır. Güvenirliğine ilişkin bulunan Cronbach Alfa değerlerinden hareketle ölçeğin güvenilir bir ölçek olduğu ve faktör analizi sonuçlarından hareketle de ölçeğin yapı geçerliliğinin olduğu söylenebilir. Yaşam tarzı ölçeğine ilişkin faktör analizi ve güvenilirlik analizi sonuçları Tablo 1'de gösterilmektedir.

Tablo 1: Yaşam Tarzı Ölçeğinin Faktör Yapısı

\begin{tabular}{|c|c|c|c|c|}
\hline Boyut & Madde & $\begin{array}{l}\text { Faktör } \\
\text { Yükü }\end{array}$ & $\begin{array}{l}\text { Açıklanan } \\
\text { Varyans }\end{array}$ & $\begin{array}{l}\text { Cronbach } \\
\text { Alfa }\end{array}$ \\
\hline \multirow{6}{*}{$\begin{array}{l}\text { İndirim Takipçileri } \\
\text { (Özdeğer=5.649) }\end{array}$} & Alışverişe Çoğunlukla İndirim Zamanlarında Çıkarım & 0,877 & \multirow{6}{*}{14,126} & \multirow{6}{*}{0,881} \\
\hline & $\begin{array}{l}\text { Indirimdeki ürünleri Başkalarından Önce Yakalayıp Bulmaktan Çok } \\
\text { Zevk Alırım }\end{array}$ & 0,847 & & \\
\hline & Özel İndirimli ürünler Satın Alırım & 0,813 & & \\
\hline & Genellikle İndirimli Satış Duyuruları İçin Reklamları İzlerim & 0,776 & & \\
\hline & Pazarlık Ederek Alışveriş Yapmaktan Hoşlanırım & 0,708 & & \\
\hline & Her Zaman Para Sıkıntısı Çekerim & 0,594 & & \\
\hline \multirow{5}{*}{$\begin{array}{l}\text { Evcimenler } \\
\text { (Özdeğer=4.321) }\end{array}$} & $\begin{array}{l}\text { Çocuklarımın İyi Şeyler Öğrenmeleri İçin Vakit Harcayıp, Çaba } \\
\text { Gösteririm }\end{array}$ & 0,784 & \multirow{5}{*}{11,681} & \multirow{5}{*}{0,795} \\
\hline & Ailem/Çocuklarım Hayatımda En Önemli Varlığımdır & 0,743 & & \\
\hline & Manevi Değerlere Maddi Değerlerden Daha Fazla Önem Veririm & 0,709 & & \\
\hline & $\begin{array}{l}\text { Bir Tüketici Olarak Haklarımıza Sahip Çıkmamız Gerektiğini } \\
\text { Düşünürüm }\end{array}$ & 0,682 & & \\
\hline & Evimi Genellikle Düzgün ve Temiz Tutarım & 0,643 & & \\
\hline \multirow{6}{*}{$\begin{array}{l}\text { Yenilik ve Teknoloji } \\
\text { Ustaları } \\
\text { (Özdeğer=2.637) }\end{array}$} & Hayatımda Genellikle Heyecan Ararım & 0,830 & \multirow{6}{*}{10,060} & \multirow{6}{*}{0,760} \\
\hline & Yeni ve Farklı Bir Şeyler Yapmayı Severim & 0,765 & & \\
\hline & Yaşamıma Yenilikler ve Değişiklikler Girmesini Hoş Karşılarım & 0,623 & & \\
\hline & Riskli İşler Hoşuma Gider & 0,603 & & \\
\hline & Kendin Kur/yap ürünleri Satın Almaktan Hoşlanırım & 0,576 & & \\
\hline & Her Zaman En Son Teknoloji ve En Yeni ürünlerle Illgilenirim & 0,504 & & \\
\hline \multirow{5}{*}{$\begin{array}{l}\text { Marka ve Moda Delileri } \\
\text { (Özdeğer=2.135) }\end{array}$} & Modayı Yakından Takip Ederim & 0,715 & \multirow{5}{*}{9,703} & \multirow{5}{*}{0,742} \\
\hline & Kişisel Bakımıma Önem Veririm & 0,681 & & \\
\hline & Arkadaşlarımla ürün ve Markalar Hakkında Konuşarak Vakit Geçiririm & 0,673 & & \\
\hline & Kişiliğimi ve Tarzımı Yansıtacak ürünler Satın Almak İsterim & 0,649 & & \\
\hline & Gösteriş Yapmayı Severim & 0,580 & & \\
\hline Lider Ruhlular & İnsanları Yönetmeyi Severim & 0,785 & 8,761 & 0,774 \\
\hline
\end{tabular}




\begin{tabular}{|c|c|c|c|c|}
\hline \multirow[t]{3}{*}{ (Özdeğer=1.859) } & $\begin{array}{l}\text { Kendi Kararlarımı Kendim Veririm, Kimse Bana Ne Yapacağımı } \\
\text { Söyleyemez }\end{array}$ & 0,762 & & \\
\hline & Kendimi İyi Bir Lider Olarak Tanımlıyorum & 0,720 & & \\
\hline & Çoğu İnsandan Daha Yetenekliyimdir & 0,585 & & \\
\hline \multirow{3}{*}{$\begin{array}{l}\text { Sağlıkçılar } \\
\text { (Özdeğer=1.506) }\end{array}$} & Gıda Alışverişlerinde Genellikle Kalorisi Düşük Ürünler Satın Alırım & 0,794 & \multirow{3}{*}{8,111} & \multirow{3}{*}{0,745} \\
\hline & Gıda Paketlerinin Üzerindeki Besin, Yağ ve Kalori İçeriklerini Okurum & 0,774 & & \\
\hline & $\begin{array}{l}\text { Çevreyle Dost Olduğuna İnandığım Ürünleri Satın Almak İ̧̧in Daha } \\
\text { Fazla Öderim }\end{array}$ & 0,762 & & \\
\hline
\end{tabular}

Yaşam tarzı ölçeğinin faktör analizi değerlendirilmesinde öz değeri birden büyük faktörlerin ele alınmasına, değişkenlerin faktör içerisindeki ağırlığını gösteren faktör yüklerinin yüksek olmasına, aynı değişken için faktör yüklerinin birbirine yakın olmamasına dikkat edilmiştir. Ölçeği oluşturan faktörlerin güvenirlik katsayıları ve açıklanan varyans oranlarının yüksek olması ölçeğin güçlü bir faktör yapısına sahip olduğunu göstermiştir. Ölçekteki faktörlerin puanları hesaplanırken faktördeki maddelerin değerleri toplandıktan sonra madde sayısına bölünerek (aritmetik ortalama alınarak) faktör puanları elde edilmiştir. Verilerin normal dağılıp dağılmadığına ilişkin yapılan normallik testinde basıklık ve çarpıklık değerlerine bakıldığında bütün değerlerin $-1,5$ ile $+1,5$ arasında yer aldığı görülmüştür. Tabachnick ve Fidell'e göre (1996) bu değerler arasında kalan verilerin normal dağıldığı kabul edilebilir. Hatta bazı araştırmacılar bu değerin -2 ile +2 arasında olduğunda bile verilerin normal olarak dağıldığı varsayımının kabul edilebileceğini öne sürmektedirler (George ve Mallery, 2000). Bu çalışmada verilerin normal dağıldığı varsayımının kabulünden dolayı parametrik bir test olan ANOVA'nın kullanılmasında bir sakınca görülmemiştir.

Tablo 2: Değerlerin Alışveriş Merkezine Gitme Sıklığına Göre Karşılaştırılması

\begin{tabular}{|c|c|c|c|c|c|c|c|}
\hline & Grup & $\mathbf{N}$ & Ort & Ss & $\mathbf{F}$ & $\mathbf{p}$ & Fark \\
\hline \multirow{4}{*}{ Heyecan Arama } & Her Gün & 27 & 3,815 & 0,834 & \multirow{4}{*}{7,086} & \multirow{4}{*}{0,000} & \multirow{4}{*}{$\begin{array}{l}1>2 \\
1>3 \\
1>4 \\
3>4\end{array}$} \\
\hline & Sadece Hafta Sonları & 49 & 2,939 & 1,281 & & & \\
\hline & Fırsat Bulduğumda Giderim & 292 & 3,103 & 1,341 & & & \\
\hline & Avm'ye Pek Gitmem & 82 & 2,549 & 1,441 & & & \\
\hline \multirow{4}{*}{ Yaşamda Mutluluk ve Haz } & Her Gün & 27 & 4,852 & 0,362 & \multirow{4}{*}{6,674} & \multirow{4}{*}{0,000} & \multirow{4}{*}{$\begin{array}{l}1>2 \\
1>3 \\
1>4 \\
3>4\end{array}$} \\
\hline & Sadece Hafta Sonları & 49 & 3,939 & 1,360 & & & \\
\hline & Firsat Bulduğumda Giderim & 292 & 4,223 & 1,040 & & & \\
\hline & Avm'ye Pek Gitmem & 82 & 3,878 & 1,137 & & & \\
\hline \multirow{4}{*}{$\begin{array}{c}\text { Diğer İnsanlarla İyi İlişkiler } \\
\text { Kurma }\end{array}$} & Her Gün & 27 & 4,074 & 0,550 & \multirow{4}{*}{2,056} & \multirow{4}{*}{0,105} & \\
\hline & Sadece Hafta Sonları & 49 & 4,020 & 0,946 & & & \\
\hline & Fırsat Bulduğumda Giderim & 292 & 4,116 & 1,059 & & & \\
\hline & Avm'ye Pek Gitmem & 82 & 4,390 & 0,857 & & & \\
\hline \multirow{4}{*}{ Öz Saygı } & Her Gün & 27 & 4,889 & 0,320 & \multirow{4}{*}{3,174} & \multirow{4}{*}{0,024} & \multirow{4}{*}{$\begin{array}{l}1>2 \\
1>3 \\
1>4\end{array}$} \\
\hline & Sadece Hafta Sonları & 49 & 4,408 & 0,814 & & & \\
\hline & Fırsat Bulduğumda Giderim & 292 & 4,473 & 0,734 & & & \\
\hline & Avm'ye Pek Gitmem & 82 & 4,549 & 0,688 & & & \\
\hline \multirow{4}{*}{ Diğer Bireylerden Saygı Görme } & Her Gün & 27 & 4,296 & 0,465 & \multirow{4}{*}{0,732} & \multirow{4}{*}{0,533} & \\
\hline & Sadece Hafta Sonları & 49 & 4,510 & 0,545 & & & \\
\hline & Fırsat Bulduğumda Giderim & 292 & 4,411 & 0,801 & & & \\
\hline & Avm'ye Pek Gitmem & 82 & 4,500 & 0,850 & & & \\
\hline \multirow{4}{*}{ Güvende Olma } & Her Gün & 27 & 2,407 & 1,824 & \multirow{4}{*}{21,664} & \multirow{4}{*}{0,000} & $2>1$ \\
\hline & Sadece Hafta Sonları & 49 & 4,408 & 0,840 & & & $3>1$ \\
\hline & Fırsat Bulduğumda Giderim & 292 & 3,384 & 1,565 & & & $4>1$ \\
\hline & Avm'ye Pek Gitmem & 82 & 4,378 & 1,014 & & & $2>3$ \\
\hline \multirow{4}{*}{ Aidiyet Hissi } & Her Gün & 27 & 2,519 & 1,252 & \multirow{4}{*}{7,681} & \multirow{4}{*}{0,000} & $4>1$ \\
\hline & Sadece Hafta Sonları & 49 & 3,163 & 1,612 & & & $2>3$ \\
\hline & Firsat Bulduğumda Giderim & 292 & 2,493 & 1,613 & & & $4>3$ \\
\hline & Avm'ye Pek Gitmem & 82 & 3,317 & 1,323 & & & \\
\hline Kişisel Gelişim & Her Gün & 27 & 3,667 & 0,832 & 7,876 & 0,000 & $2>1$ \\
\hline
\end{tabular}




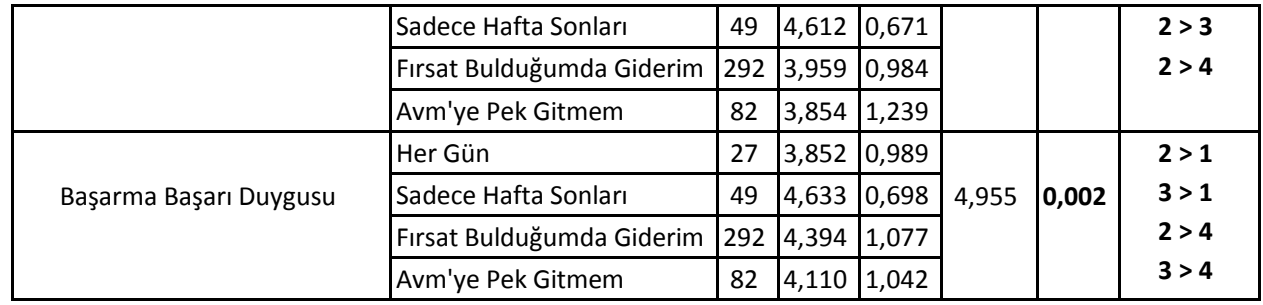

Araştırmaya katılan tüketicilerin değerlere göre aldıkları puan ortalamalarının alışveriş merkezine gitme sıklığı değişkenine göre anlamlı bir farklıık gösterip göstermediğini belirlemek amacıyla yapılan tek yönlü varyans analizi (ANOVA) sonucunda grup ortalamaları arasındaki fark istatistiksel açıdan anlamlı bulunmuştur. Buna göre heyecan arama, yaşamda mutluluk ve haz, öz saygı, güvende olma, aidiyet hissi, kişisel gelişim ve başarma duygusu değerleri ile alışveriş merkezine gitme sıklıkları arasında anlamlı farklılıklar olduğu görülmektedir. Alışveriş merkezine "her gün" giderim diyenlerin heyecan arama, yaşamda mutluluk ve haz ile öz saygı değer puanları, alışveriş merkezine "sadece hafta sonları giderim", "fırsat bulduğumda giderim" ile "alışveriş merkezine pek gitmem" diyenlerin puanlarından yüksek bulunmuştur. Aidiyet hissi, güvende olma ve kişisel gelişim değerlerine önem verenlerin ise alışveriş merkezine ya hafta sonları gittikleri ya da alışveriş merkezine gitmeyi pek tercih etmedikleri görülmektedir. Diğer insanlarla iyi ilişkiler kurma ve diğer bireylerden saygı görme değerlerinin ortalamaları alışveriş merkezine gitme sıklığına göre farklılaşmadığı, buna göre bu iki değer ortalamaları ile alışveriş merkezine gitme sıklığı arasında anlamlı bir ilişkinin olmadığı görülmüştür.

Tablo 3: Sınıflandırılmış Kişisel Değerlerin Alışveriş Merkezine Gitme Sıklığına Göre Karşılaştırılması

\begin{tabular}{|c|c|c|c|c|c|c|c|}
\hline & Grup & $\mathbf{N}$ & Ort & Ss & $\mathbf{F}$ & $\mathbf{p}$ & Fark \\
\hline \multirow{4}{*}{ Hazcı Değer } & Her Gün & 27 & 4,247 & 0,486 & \multirow{4}{*}{4,380} & \multirow{4}{*}{0,005} & \multirow{4}{*}{$\begin{array}{l}1>2 \\
1>3 \\
1>4\end{array}$} \\
\hline & Sadece Hafta Sonları & 49 & 3,633 & 1,028 & & & \\
\hline & Firsat Bulduğumda Giderim & 292 & 3,814 & 0,867 & & & \\
\hline & Avm'ye Pek Gitmem & 82 & 3,606 & 0,833 & & & \\
\hline \multirow{4}{*}{ Empatik Değerler } & Her Gün & 27 & 3,528 & 0,785 & \multirow{4}{*}{11,165} & \multirow{4}{*}{0,000} & \multirow{4}{*}{$\begin{array}{l}2>1 \\
4>1 \\
2>3 \\
4>3\end{array}$} \\
\hline & Sadece Hafta Sonları & 49 & 4,122 & 0,715 & & & \\
\hline & Fırsat Bulduğumda Giderim & 292 & 3,690 & 0,875 & & & \\
\hline & Avm'ye Pek Gitmem & 82 & 4,186 & 0,695 & & & \\
\hline \multirow{4}{*}{$\begin{array}{c}\text { Kendini Gerçekleştirme } \\
\text { Değeri }\end{array}$} & Her Gün & 27 & 3,759 & 0,881 & \multirow{4}{*}{7,098} & \multirow{4}{*}{0,000} & \multirow{4}{*}{$\begin{array}{l}2>1 \\
3>1 \\
2>3 \\
2>4\end{array}$} \\
\hline & Sadece Hafta Sonları & 49 & 4,622 & 0,625 & & & \\
\hline & Firsat Bulduğumda Giderim & 292 & 4,176 & 0,908 & & & \\
\hline & Avm'ye Pek Gitmem & 82 & 3,982 & 1,041 & & & \\
\hline
\end{tabular}

Araştırmaya katılan tüketicilerin hazcı değer puanları ortalamalarının alışveriş merkezine gitme sıklığı değişkenine göre anlamlı bir farklılık gösterip göstermediğini belirlemek amacıyla yapılan tek yönlü varyans analizi (Anova) sonucunda grup ortalamaları arasındaki fark istatistiksel açıdan anlamlı bulunmuştur $(F=4,380 ; p=0,005<0.05)$. Farklııkların kaynaklarını belirlemek amacıyla tamamlayıcı post-hoc analizi yapılmıştır. Alışveriş merkezine gitme sıklığı "her gün" olanların hazcı değer puanları $(4,247 \pm 0,486)$, alışveriş merkezine "sadece hafta sonu giderim" "fırsat bulduğumda giderim" ve "alışveriş merkezine pek gitmem" diyenlerin hazcı değer puanlarından $(3,606 \pm 0,833)$ yüksek bulunmuştur. Araştırmaya katılan tüketicilerin empatik değerlerinin alışveriş merkezine gitme sıklığı değişkenine göre anlamlı bir farklılık gösterip göstermediğini belirlemek amacıyla yapılan tek yönlü varyans analizi (ANOVA) sonucunda grup ortalamaları arasındaki fark istatistiksel açıdan anlamlı bulunmuştur $(F=11,165 ; p=0,000<0.05)$. Farklııkların kaynaklarını belirlemek amacıyla tamamlayıcı Post-Hoc analizi yapılmıştır. Buna göre alışveriş merkezine "sadce hafta sonu giderim" diyenler ile "alışveriş merkezine pek gitmem" diyenlerin empatik değer puan ortalamaları diğer gruplara göre daha yüksek çıkmıştır.

Araştırmaya katılan tüketicilerin kendini gerçekleştirme değeri puanları ortalamalarının alışveriş merkezine gitme sıklığı değişkenine göre anlamlı bir farklılık gösterip göstermediğini belirlemek amacıyla yapılan tek yönlü varyans analizi (Anova) sonucunda grup ortalamaları arasındaki fark istatistiksel açıdan anlamlı bulunmuştur $(F=7,098 ; p=0,000<0.05)$. Farklılıkların kaynaklarını belirlemek amacıyla tamamlayıcı Post-Hoc analizi yapılmıştır. Alışveriş merkezine "yalnızca hafta sonları" gidenlerin kendini gerçekleştirme değeri puanları her gün giden, fırsat bulduğunda giden ve AVM'ye pek gitmeyen tüketicilere göre daha yüksek bulunmuştur. Öz olarak belirtmek gerekirse, hazcı değere sahip tüketicilerin alışveriş merkezlerine "her gün" gittikleri; empatik değere sahip tüketicilerin "fırsat bulduklarında gittikleri" ya da "alıveriş merkezine 
pek gitmedikleri"; kendini gerçekleştirme değerine sahip tüketicilerin ise "sadece hafta sonları" alışveriş merkezine gittikleri görülmüştür. Tüketicilerin yaşam tarzlarının alışveriş merkezine gitme sıklığına göre anlamlı bir farklılık gösterip göstermediğini belirlemek amacıyla yapılan tek yönlü varyans analizi (ANOVA) sonucunda grup ortalamaları arasındaki fark istatistiksel açıdan anlamlı bulunmuştur. Yapılan Post-Hoc analizine göre farklılıkların hangi gruplardan kaynaklandığı öğrenilmiştir. Buna göre "Indirimleri takip eden" tüketicilerin alışveriş merkezine pek gitmedikleri; markaya, modaya düşkün, yenilikleri takip eden, lider ruhlu yaşam tarzına sahip tüketicilerin ise alışveriş merkezine "her gün" veya "fırsat bulduğumda giderim" cevabını verdikleri görülmektedir. Sağlıklı yaşam tarzına sahip tüketiciler ise alışveriş merkezlerine "sadece hafta sonları" veya "fırsat bulduklarında" gittiklerini belirtmişlerdir. Bu sonuçlardan tüketicilerin yaşam tarzlarına göre farklı sıklıkta AVM'leri ziyaret ettikleri anlaşılmaktadır.

Tablo 4: Yaşam Tarzı Gruplarının Alışverış Merkezlerine Gitme Sıklıklarına Göre Karşılaştırılması

\begin{tabular}{|c|c|c|c|c|c|c|c|}
\hline & Grup & $\mathbf{N}$ & Ort & Ss & $\mathbf{F}$ & $\mathbf{p}$ & Fark \\
\hline \multirow{4}{*}{ İndirim Takipçileri } & Her Gün & 27 & 2,617 & 0,883 & \multirow{4}{*}{7,213} & \multirow{4}{*}{0,000} & \multirow{4}{*}{$\begin{array}{l}4>1 \\
4>2 \\
4>3\end{array}$} \\
\hline & Sadece Hafta Sonları & 49 & 2,990 & 0,800 & & & \\
\hline & Fırsat Bulduğumda Giderim & 292 & 2,884 & 0,959 & & & \\
\hline & Avm'ye Pek Gitmem & 82 & 3,376 & 0,961 & & & \\
\hline \multirow{4}{*}{ Evcimenler } & Her Gün & 27 & 4,341 & 0,332 & \multirow{4}{*}{0,634} & \multirow{4}{*}{0,594} & \\
\hline & Sadece Hafta Sonları & 49 & 4,147 & 0,706 & & & \\
\hline & Fırsat Bulduğumda Giderim & 292 & 4,258 & 0,657 & & & \\
\hline & Avm'ye Pek Gitmem & 82 & 4,276 & 0,673 & & & \\
\hline \multirow{4}{*}{ Yenilik ve Teknoloji Ustaları } & Her Gün & 27 & 3,630 & 0,315 & \multirow{4}{*}{3,301} & \multirow{4}{*}{0,020} & \multirow{4}{*}{$\begin{array}{l}1>2 \\
1>4 \\
3>4\end{array}$} \\
\hline & Sadece Hafta Sonları & 49 & 3,191 & 0,827 & & & \\
\hline & Fırsat Bulduğumda Giderim & 292 & 3,326 & 0,782 & & & \\
\hline & Avm'ye Pek Gitmem & 82 & 3,118 & 0,963 & & & \\
\hline \multirow{4}{*}{ Marka ve Moda Delileri } & Her Gün & 27 & 4,082 & 0,613 & \multirow{4}{*}{29,756} & \multirow{4}{*}{0,000} & \multirow{4}{*}{$\begin{array}{l}1>2 \\
1>3 \\
1>4 \\
2>4 \\
3>4\end{array}$} \\
\hline & Sadece Hafta Sonları & 49 & 3,441 & 0,955 & & & \\
\hline & Fırsat Bulduğumda Giderim & 292 & 3,513 & 0,658 & & & \\
\hline & Avm'ye Pek Gitmem & 82 & 2,751 & 0,960 & & & \\
\hline \multirow{4}{*}{ Lider Ruhlular } & Her Gün & 27 & 4,019 & 0,658 & \multirow{4}{*}{17,533} & \multirow{4}{*}{0,000} & \multirow{4}{*}{$\begin{array}{l}1>2 \\
1>4 \\
2>4 \\
3>4\end{array}$} \\
\hline & Sadece Hafta Sonları & 49 & 3,556 & 0,729 & & & \\
\hline & Fırsat Bulduğumda Giderim & 292 & 3,803 & 0,790 & & & \\
\hline & Avm'ye Pek Gitmem & 82 & 3,098 & 1,031 & & & \\
\hline \multirow{4}{*}{ Sağlıkçılar } & Her Gün & 27 & 2,543 & 0,868 & \multirow{4}{*}{12,999} & \multirow{4}{*}{0,000} & \multirow{4}{*}{$\begin{array}{l}2>1 \\
3>1 \\
2>4 \\
3>4\end{array}$} \\
\hline & Sadece Hafta Sonları & 49 & 3,327 & 0,862 & & & \\
\hline & Fırsat Bulduğumda Giderim & 292 & 3,477 & 0,937 & & & \\
\hline & Avm'ye Pek Gitmem & 82 & 2,935 & 1,090 & & & \\
\hline
\end{tabular}

\section{SONUÇ}

Değerler ve yaşam tarzının tüketicilerin davranışlarını etkilediği ve kişinin öncelediği değerlere ve sahip olduğu yaşam tarzına göre ürün ve hizmet tercihinde bulunduğu, gideceği yerleri, parasını nereye harcayacağı ve zamanını nasıl geçireceği yine bu değerler ve yaşam tarzına göre belirlediği alan yazında belirtilmektedir. Bu araştırmada tüketicilerin yaşam tarzı ve sahip oldukları kişisel değerlerin alışveriş merkezini ziyaret etme sıklığına göre farklılaşıp farkılışmadığı araştırılmıştır. Belli bir yaşam tarzının göstergesi olarak kabul edilen AVM'ler, sunduğu olanaklar, mimari yapısı, aynı anda birçok markaya ve ürün/hizmete ulaşılabilir olması gibi nedenlerle tüketicileri kendine çekmektedir. Alışveriş merkezini ziyaret edenlerin farklı beklentileri olması ve farklı nedenlerle AVM'ye gidiyor olmaları değerler ve yaşam tarzının alışveriş merkezi ziyaretleri üzerinde etkili olduğunu bizlere göstermektedir. Vural ve Yücel (2006: 104) bir ailenin farklı ilgi alanlarına sahip tüm üyelerinin iş saatleri dışında alışveriş merkezinde kendilerine göre birer aktivite bulabileceklerini söylemektedir. Bu da farklı yaşam tarzlarına sahip tüketicilerin AVM'leri farkı sıklıklarla ziyaret edebileceğini göstermektedir. Bazı tüketiciler yalnızca 
vitrinlere bakmak, yeni ve son moda ürünlerden haberdar olmak için giderken, bazıları indirimleri takip etmek, ucuz ürünler satın almak ve ekonomik bir alışveriş yapabilmek için AVM'ye gitmeyi tercih etmektedir. Bazı tüketiciler ise yalnızca sosyalleşmek, aile üyeleriyle - arkadaşlarıyla hoş vakit geçirmek ve gündelik hayatın sıkıntılarından uzaklaşmak için alışveriş merkezine gitmektedir. Yalnızca yemek yemek için gidenler de olabilmektedir. Bu kişiler doğrudan AVM'nin yemek katına yönelmekte ve vitrinlere bakmamaktadır veya sonra bakmaktadır. Değerler ve yaşam tarzına göre alışveriş merkezi ziyaret sıklığının değişip değişmediğini öğrenmek amacıyla yapılan bu araştırma sonucunda farklı değerlere, farklı yaşam tarzlarına sahip tüketicilerin farklı sıklıklarla alışveriş merkezlerini ziyaret ettikleri görülmüştür. Değerler yönünden bakıldığında alışveriş merkezini "her gün" ziyaret edenlerin daha çok yaşamda mutluluk ve haz, heyecan arama ve öz saygı değerlerini öncelediği görülmüştür. Alışveriş merkezine "sadece hafta sonu" giden veya AVM'ye pek gitmeyen tüketicilerin ise aidiyet, güvende olma ve kişisel gelişim değerlerine önem verdikleri anlaşılmıştır. Diğer insanlarla iyi ilişkiler kurma ve diğer bireylerden saygı görme değerlerinin ortalamaları alışveriş merkezine gitme sıklığına göre farklılaşmadığı, buna göre bu iki değer ortalamaları ile alışveriş merkezine gitme sıklı̆̆ı arasında anlamlı bir ilişkinin olmadığı görülmüştür. Değerlere Kahle'nin yaptığı üçlü sınıflandırma gözüyle bakıldığında ise durum çok daha özet olarak görülmektedir. Buna göre hazcı değere sahip tüketicilerin alışveriş merkezine her gün gittikleri, empatik değerlere sahip tüketicilerin alışveriş merkezine gitmeyi pek tercih etmedikleri, kendini gerçekleştirme değerine sahip tüketicilerin ise sadece hafta sonları alışveriş merkezlerine gittikleri görülmüştür.

Yaşam tarzı açısından değerlendirildiğinde Indirim takipçilerinin alışveriş merkezlerine pek gitmediği, marka ve modaya düşkün, yenilikleri ve teknolojiyi takip eden, lider ruhlu tüketicilerin alışveriş merkezini her gün ziyaret ettikleri ve sağıılarına dikkat edenlerin ise alışveriş merkezine daha çok fırsat bulduklarında gittikleri görülmüştür. Alışveriş merkezleri ile ilgili yapılan çalışmalarda çok çeşitli ve farklı özellikteki tüketicilerin AVM'leri ziyaret ettikleri ve AVM'leri çekici kılan farklı faktörlerin olduğu ortaya çıkmaktadır. Örneğin yapılan bir çalışmada alışveriş yapanların bakış açısıyla 6 farklı AVM cazibesi faktörü bulunmuştur. Bunlar sırasıyla, konfor, eğlence, çeşitlilik, AVM ruhu, kolaylık ve lüks faktörleridir. Ayrıca, yapılan kümeleme analizi sonucunda rahat müşteriler, talepkar müşteriler ve faydacı müşteriler olmak üzere üç farklı AVM müşteri tipi ortaya konulmuştur (El-Adly, 2007). Bu kümelerdeki tüketicilerin herbirinin farklı özelliklere, farklı değerlere ve farklı yaşam tarzlarına sahip olduğu söylenebilir. Talepkar müşterilerin beklentileri faydacı müşterilerinki ile aynı olmayacaktır. Yine rahat müşterilerin beklentileri ise talepkar müşterilerinkinden farklı olacaktır. Ve bu farklılıkların onların sahip oldukları değerler ve yaşam tarzlarından kaynaklandığı söylenebilir. Sonuçlar bir bütün olarak değerlendirildiğinde AVM yöneticilerinin çok daha özel ve müşteri odaklı stratejilere ihtiyacı olduğu, alışveriş merkezlerinin dış görünümünden ziyade içeride yer alan unsurlara (mağazalara, atmosfere, sunulan markalara, hizmetlere vs.) dikkat etmeleri önerilebilir. Artan rekabet düzeyi, değişen tüketici profilleri ve teknoloji olanaklarının genişlemesi ve buna bağlı olarak e-ticaretin yaygınlaşması birer tehdit unsuru olarak alışveriş merkezlerini etkilemektedir. Wakefield and Baker (1998: 515) alışveriş merkezlerinin azalan popülaritesini üç ana başlıkta açıklamaktadır. Bunlardan birincisi, tüketicilerin giderek artan meşguliyetleri ve alışveriş için daha az zamanları oluşudur. Bu nedenle, tüketicilerin alışveriş merkezi ziyaret sıklıkları her geçen gün azalmaktadır. İkincisi, alışveriş merkezi sayısının artması doolayısıyla, tüketicilerin en çok mağaza olan ve en çok çeşitte ürün/hizmet sunan alışveriş merkezlerini tercih ediyor olması. Üçüncüsü ise, çok az tüketicinin alışveriş merkezine giderek alışveriş deneyiminin keyfini çıkarttığıdır. Bu sebeple alışveriş merkezlerinde sunulan ürünlerin/hizmetlerin geliştirilmesi oraya gelen müşterilerin iyi anlaşılmasına bağlıdır. Müşterileri en iyi anlamanın araçlarından birisi de onları değerler ve yaşam tarzına göre bölümlendirmektir. Alışveriş merkezi yöneticilerine, değerlerine ve yaşam tarzlarına göre tüketicileri bölümlere ayırmaları ve alışveriş merkezininin güçlü yönleri ile ilişkili olan bir veya daha fazla bölümü hedef kitle seçip bunlara yönelik strateji geliştirmeleri tavsiye edilmektedir.

\section{KAYNAKLAR}

Akat, Ö., Taşkın, Ç. ve Özdemir, A. (2016). “Uluslararası Alışveriş Merkezi Tüketicilerinin Satın Alma Davranışı: Bursa illinde Bir Uygulama” Sosyal Bilimler Dergisi, 2016/2

Arnold, M. J. ve Reynold, K. E. (2003). "Hedonic shopping motivations”, Journal of Retailing, (79): 77-95

Babin, B. J. Darden, W. R. ve Griffin, M. (1994). "Work and/or Fun: Measuring Hedonic and Utilitarian Shopping Value", Journal of Consumer Research, (20): 644-656

Bloch, P. H., Ridgway, N. M. ve Sherrel, D. L. (1989). "Extending the concept of shopping: An investigation of browsing activity", Journal of the Academy of Marketing Science, 17 (1): 13- 21.

Bozgeyikli, H. (2010). "The relationship between high school students' psychological needs and human value perceptions", Procedia Social and Behavioral Sciences, (9): 1798-1804

Catalin, M. C. ve Andreea, P. (2014). "Brands as a mean of consumer self-expression and desired personal lifestyle", $2^{\text {nd }}$ World Conference on Business, Economics and Management, Procedia - Social and Behavioral Science, (109), ss.103-107

Çakmak, A. Ç. (2012). "Ziyaretçilerin Alışveriş Merkezlerini Tercih Etme Nedenlerinin Araştırılması: Karabük Şehir Merkezinde Bir Uygulama", Niğde Üniversitesi iiBF Dergisi, 5(2): 195-215 
El-Adly, M. I. (2007). "Shopping malls attractiveness: a segmentation approach", International Journal of Retail \& Distribution Management, 35 (11), ss.935-950

Erkip, F. (2005). "The rise of the shopping mall in Turkey: the use and appeal of a mall in Ankara", Cities, 22 (2): 89-108

Gutierrez, B. P. B. (2004). “Determinants of Planned and Impulse Buying: The Case of the Philippines", Asia Pacific Management Review 9(6), 1061-1078

Kahle, L. R. (1986). “The Nine Nation of North America and the Value Basis of Geographic Segmentation”, Journal of Marketing, (50), 37-47

Kahraman, A. B. (2011). “Hacettepe Üniversitesi ile Erciyes Üniversitesi'nde Görev Yapan Öğretim Üyelerinin Tüketim Alışanlıkları ve Yaşam Tarzı Profilleri", Hacettepe Üniversitesi Sosyolojik Araştırmalar E-Dergisi.

Kim, H. Y. ve Kim, Y. K (2008). "Shopping enjoyment and store shopping modes: the moderating influence of chronic time pressure", Journal of Retailing and Consumer Services, (15): 410-419

Kim, Y. K. (2002). "Consumer Value: an application to mall and internet shopping", International Journal of Retail \& Distribution Management, 30 (12): 595-602

Köksal, Y. ve Aydın, E. E. (2015). "Tüketicilerin Alışveriş Merkezleri Algııı Üzerine Karşıllaştırmalı Bir İnceleme: Göller Bölgesi Örneği”, Uluslararası Yönetim, iktisat ve Iş̧letme Dergisi, 11(24): 231-248

Krejcie, R. V. ve Morgan, D. W. (1970). "Determining Sample Size for Research Activities", Educational and Psychological Measurement, (30), ss.607-610

Langrehr, F. W. (1991). "Retail shopping mall semiotics and hedonic consumption", Advances in Consumer Research, (18): 428-433.

George, D. ve Mallery, P. (2000). SPSS for windows step by step (3rd ed.)., Allyn \& Bacon

NG, C. F. (2003). "Satisfying shoppers' psychological needs: from public market to cyber-mall”, Journal of Environmental Psychology, (23): 439-55.

Roy, A. (1994). “Correlates of mall visit frequency”, Journal of Retailing, (70): 139-161.

Ruiz, J. P., Chebat, J. C. ve Hansen, P. (2004). "Another trip to the mall: a segmentation study of customers based on their activities", Journal of Retailing and Consumer Services (11): 333-350

Soininen, M. ve Merisso-Storm, T. (2010). "The lifestyle of the youth, their everyday life and relationships in Finland", Procedia-Social and Behavioral Science, (2), ss.1665-1669.

Şentürk, Ü. (2012). "Tüketim Toplumu Bağlamında Boş Zamanların Kurumsallaştırdığı Bir Mekân: Alışveriş Merkezleri”, Pamukkale Üniversitesi Sosyal Bilimler Enstitüsü Dergisi, (13): 63-77

Tabachnick, B. G. ve Fidell, L. S. (1996). Using multivariate statistics (3rd ed.). Boston: Allyn \& Bacon

Taylor, S. L. ve Cosenza, R. M. (2002). "Profiling Later Aged Female Teens: Mall Shopping Behavior and Clothing Choice," Journal of Consumer Marketing, 19 (5): 393-408.

Terblanche, N.S. (1999). "The perceived benefits derived from visits to a super regional shopping centre: an exploratory study", South Africa Journal of Business Management, 30 (4): 141-6.

Verdil, A. (2007). Mekân-davranış İlişkisinin Dönüşümü: Alışveriş Merkezlerinin Mekânsal Dizim Yöntemiyle İncelenmesi, İstanbul Teknik Üniversitesi Fen Bilimleri Enstitüsü, Yüksek Lisans Tezi

Vural, T. ve Yücel, A. (2006). "Çağımızın yeni kamusal mekânları olan alışveriş merkezlerine eleștirel bir bakıș" iTÜ Mimarlık, Planlama, Tasarım Dergisi, 5 (2): 97-106.

Wakefield, K. L. ve Baker, J. (1998). "Excitement at the mall: Determinants and effects on shopping response", Journal of Retailing, (74): 515-540.

Wong, G., Yu, L. ve Yuan, L. L. (2001). "SCATTR: an instrument for measuring shopping centre attractiveness", International Journal of Retail \& Distribution Management, 29 (2): 76-86.

Yaraş, E., Özbük, M. Y. ve Göncü, Z. Ü. (2016). "Tüketicilerin Alışveriş Merkezi Tercihlerini Etkileyen Faktörler", Sosyal ve Ekonomik Araştırmalar Dergisi, (32): 274-285

Yazıcıoğlu, Y. ve Erdoğan, S. (2014). SPSS Uygulamalı Bilimsel Araştırma Yöntemleri, Dördüncü Baskı, Detay Yayınclık: Ankara 